\title{
A Case Study of Reading Comprehension Instruction of Students with Learning Difficulties in Elementary School
}

\author{
Juhanaini, Rona Wulandari, Endang Rochyadi \\ Department of Special Education Needs, \\ Indonesia University of Education, \\ Bandung, Indonesia \\ juhanaini@upi.edu
}

\begin{abstract}
Reading instruction in the early classes no longer focuses on the ability to read early. Curriculum analysis shows that students in the second grade of elementary school are required to be able to understand the text. There is also reading skill that students must master which is reading literal comprehension. The ability of students to read is one of the important factors of academic achievement because the reading materials are presented in written text. Students with learning difficulties have difficulty in understanding the reading material as it can be seen from the students' ability to re-convey the textbased on the questions given. One of the factors that influence students ' ability to read is the learning technique applied by the teacher. The teacher realizes that students have difficulties in understanding the text; in fact, the learning techniques applied by the teacher are not based on children's needs. This study aimed to describe the conditions of learning of reading literal comprehension by students with learning difficulties in elementary school. The method used in this study was qualitative using case study. The data analysis was carried out descriptively. The results of this study are the lack of knowledge and awareness of teachers about the importance of learning techniques based on student needs.
\end{abstract}

Keywords-reading comprehension instruction; students with learning difficulties.

\section{INTRODUCTION}

Indonesian language subject plays a role in fostering communication skills and mastery of science [1]. One of the abilities taught in this subject is reading, which is an interactive process in which the reader builds a representation of a text using an effective reading strategy [2].

Based on the analysis of Indonesian Language curriculum, the focus of reading in the second grade of elementary school is reading literal comprehension, namely reading skills that focus on understanding the facts or descriptions explicitly contained in the text [3]. Reading literal comprehension is determined by the ability of students to identify words correctly and understand the combination of words arranged in sentence form [4]. The literal comprehension reading component consists of context (the overall meaning of the text based on existing facts), facts (core information contained in the reading), and sequence (the chronological process of events) [5].

Based on the identification that has been carried out, there were elementary second-grade students who had difficulty in reading literal comprehension. Lack of understanding of students was seen when they re-wrote the text content based on the questions' given. This condition affects the capability of students to keep pace with the learning process which also gives an impact to the learning outcomes because the learning resources used in schools tend to be presented in written text, that require students to be able to understand the text.

Students with learning difficulties need different educational treatment from their classmates, so reading instruction must be arranged in accordance with children's needs. Success in reading comprehension is influenced by several factors; the teacher, the students, the learning environment, and internal conditions of students [6]. The teacher acts as a planner, implementer, and manager, as well as an evaluator of learning activities [7]. This shows that the teacher has a role in regulating the learning environment, and in deciding the methods used to increase literal comprehension of reading ability of students with learning difficulties. Based on the role of the teacher, this study aimed to describe the implementation of learning to read literal comprehension in three elementary schools in the city of Bandung.

Research relevant to the problem in this article has been carried out by reference [8] regarding the role of teachers in Indonesian Language learning activities for third grade students with learning difficulties in the Gadingan_KulonProgo elementary school. The results showed that teachers were less able to carry out their roles as informants, administrators, motivators, innovators, directors, facilitators, and evaluators in serving learning needs for students with specific learning difficulties [8]. The difference in this study with previous research lies on the number of research locations and research devoted to the implementation of a literal comprehension of reading instruction. 


\section{METHOD}

The approach used in this study was qualitative using case study, which is a strategy that aims to reveal "why" and "how" an event that is happening in a real-life context [9]. The location of the study was conducted at three elementary schools in Bandung with students who had difficulty in learning to read literal comprehension at those schools. Subjects in this study were seven children who were identified as having difficulty reading literal comprehension.

Data collection techniques were carried out through interviews, observation, and documentation. The interview process was administered in a structured manner by preparing the interview guidelines in advance [10] so that the data collected became more accurate. In the observations, the researcher only acted as an observer (not actively involved in research) [11]. Documentation was done through field notes, photos, audio recordings and videos about the implementation of learning in three elementary schools. Data testing was done through triangulation of sources by comparing the results of interviews with the contents of a document that was related, comparing the situation/perspective of a person with various opinions, and comparing observational data with interview results [12]. The data then were analyzed descriptively by describing a phenomenon in the form of characteristic activities, changes, similarity relationships, and differences in phenomena with one another [13].

\section{RESUlT AND DISCUSSION}

Teachers at three elementary schools in Bandung realized that students with learning difficulties experience problems in reading comprehension which was based on students' learning outcomes in answering questions based on the content of the text.

Based on observations and interviews that have been carried out, the condition of reading comprehension learning in three elementary schools can be divided into three aspects, namely the teacher's knowledge of the actual condition of literal comprehension, the reading ability of students with learning difficulties, and the implementation of learning.

Knowledge of the actual condition of literal comprehension reading ability on students with learning difficulties is lack because the teacher only sees the lack of students' knowledge based on the ability to answer questions. The term "assessment" is a new thing that is known so that the teacher does not know that assessment is a process to know the potential, shortcomings, and needs of children in reading.

Reading activity was done through simultaneous reading and individual reading based on the text available in secondgrade thematic books. The methods used by the teacher in teaching were lectures and assignments. The lecture method was used by the teacher if the text contained concepts and required students to understand the material being taught. One of the materials was understanding the question mark in the question sentence. This material requires the student to be able to understand various forms of question words (what, who, where, when, why, and how) and their functions and understanding the sentence of the question through the use of question marks. The assignment method was done by the teacher to instruct students to work on a number of tasks contained in the book based on the text and material that have been read and taught.

During reading instruction, teachers did not provide opportunities for students who had difficulty in learning to be actively involved in the learning process, for example by giving students the opportunity to express their experiences related to the material being taught. Teachers tended to require students to master the same indicators as their classmates so that when students had difficulty learning to do the tasks' given, students could not complete the task properly.

Lack of understanding of students in reading also affected group learning activities. Other students knew that students with learning difficulties had different abilities so that in group activities there were many students who refused to invite students with learning difficulties. The teacher then placed students with learning difficulties into groups with fewer quotas of members. Group learning made students more confident when compared to do assignments individually, but it still seemed that mastery of tasks that were possessed by students with learning difficulties were different as other students.

The teacher realized that at certain times other students showed a lack of acceptance of the existence of students with learning difficulties, but sometimes the teacher did not encourage or simply convey the students to be more active in learning by taking private so their abilities were not left behind by other students. Learning treatments in the three schools were different; the teacher at one school showed concern by helping students who had learning difficulties to read the text so that they were able to complete the assignment. In the other two schools, teachers tended to ignore the existence and learning needs of those students so that each teacher gave same task instructions with other students. As a result, students with learning difficulties tended to be unable to complete the answers properly and the teacher gave a reprimand for students' inability.

The skills of teachers in teaching the material to other students were enchant, but the teacher did not apply the right learning treatment so that the existence and learning needs of students with learning difficulties became neglected. The lack of teachers' awareness of the needs of students with learning difficulties is due to the lack of teacher's knowledge of the students' condition and learning treatments that must be based on the needs of each student.

Teachers in one school revealed that improving children's abilities cannot rely on teachers only, but parents must also be involved to improve children's ability to read. Differentiation of learning will affect the social situation in the classroom because if a student is given minimum completeness criteria or different teaching material, it will make other students feel differentiated.

Teacher abilities tend to be limited to the general field, so it is assumed that teachers have difficulties in applying learning that is appropriate to the needs of students. This was also found in three elementary schools in Bandung that teachers have less 
knowledge about students with learning difficulties and the importance of learning treatment that are appropriate to the needs of children.

Based on observations and interviews, it can be concluded that all schools apply the same learning to all students in the class. In essence, the same learning for all students is inappropriate. Equalization of learning activities is inappropriate because there are many differences between students with special needs and their friends so that it requires teaching materials and practices specifically made [14].

In addition, support from the school or foundation has an important influence on the course of learning in the classroom. At one school, the teacher realized that students with learning difficulties have difficulties in understanding reading, but this condition is not supported by the awareness of the foundation that each student needs different learning.

Schools play a role in accommodating and responding to the needs of each student [15]. The existence of this role requires schools to be able to accommodate various learning styles and levels of learning, ensure the existence of an appropriate curriculum, organize the organization well and establish relationships with various elements of society [16]. This refers to all elements in the school that must play a role in supporting learning services according to students' needs.

Teacher knowledge and attitudes are the keys to education quality.[17]. In three schools, teachers tended not to know the student's condition in detail and the services that must be provided so that it becomes a problem in applying the right learning. Difficulties experienced by teachers in treating students with special needs are caused by the teacher's lack of knowledge about how to handle and apply needs-based learning.

Based on these results, it can be seen that knowledge influences individual awareness of things. Teacher's knowledge and understanding of learning difficulties can lead to learning services that are appropriate to students' needs [18].

\section{CONCLUSION}

Learning to read comprehension for students with learning difficulties in three elementary schools in the city of Bandung can be proven that it was to be not in accordance with the needs of children. This is based on the lack of knowledge and awareness of teachers regarding the actual condition of reading literal comprehension of students with learning difficulties so that it affects the learning process applied. The teacher in one school realized that students with learning difficulties need special learning treatment, but this is not balanced with support from the foundation to apply learning that is appropriate to students' needs. In other two schools, teachers did not know and understood that every child has different learning needs so that the learning treatment for all students in the class is different. The support of all parties in the school, as well as the improvement of teacher competencies, especially in a pedagogical competency, becomes an important matter so that the learning needs of each child can be well served.

\section{REFERENCES}

[1] A. Muhyidin, O. Rosidin, and E. Salpariansi, "Metode pembelajaran membaca dan menulis permulaan di kelas awal sekolah dasar," JPSD, vol. 4, no. 1, pp. 30-42, Mar. 2018

[2] M. R. Ahmadi, and A. P. Gilakjani, " reciprocal teaching strategies and their impacts on english reading comprehension. theory and practice in language studies," Theory and Practice in Language Studies, vol. 2, no. 10, pp. 2053-2060, Oct. 2012.

[3] W. I. Jude, and O. B. Ajayi,'Literal level of student's comprehension in Nigeria: a means for growing a new generation African scholars," Journal of Education and Practice, vol 3, no. 7, pp. 120-129, 2012.

[4] C. Perfetti, and J. Stafura, "Word knowledge in a theory of reading comprehension," Scientific Studies of Reading, vol. 18, no.1, pp. 22-37, 2014 .

[5] S. Goff. (2010). What are the causes and effects of literal comprehension.[Online].Available: http//:www.ehow.com/info_12044849

[6] M. Meliyawati, Pemahaman Dasar Membaca. Yogyakarta: Deepublish 2016.

[7] G. Berliner of Suyono, and Hariyanto, Belajar dan Pembelajaran Teor dan Konsep Dasar. Bandung: PT Remaja Rosdakarya, page. 187, 2014.

[8] R. Nurrahmawati, "Peran guru dalam kegiatan pembelajaran bahasa indonesia pada siswa berkesulitan belajar spesifik kelas III di sekolah dasar negeri gadingan kulon progo," Widia Ortodidaktika, vol. 5, no. 9 , 2016.

[9] R. K. Yin, Studi Kasus Desain \& Metode. Jakarta: Rajawali Press, 2011.

[10] Sugiyono, Metode Penelitian Kuantitatif, Kualitatif, dan R\&D. Bandung: Alfabeta, 2014.

[11] Tohirin, Metode Penelitian Kualitatif dalam Pendidikan dan Bimbingan Konseling. Jakarta: PT Raja Grafindo Persada, 2012.

[12] M. B. Bungin, Penelitian Kualitatif, 3rd ed. Jakarta: Kencana Prenada Media Group, 2009.

[13] N. S. Sukmadinata, Metode Penelitian Tindakan. Bandung: Remaja Rosda Karya, 2006.

[14] J. E. Ormroad, Pending Psychology Helps Students Grow and Develop Sixth Edition, vol. 1. Jakarta: Erlangga, 2008.

[15] J. I. Ibenacho, and P. I. Osuorji, "The child with learning disabilities and inclusive education," African Journal of Special Education Needs, vol. 4, no.2, pp. 197-204, 2006.

[16] S. Rustemier, and T. Booth, Learning About The Index in Use: A Study of The Use of The Index for Inclusion in Schools and LEAs in England. Bristol: Centre for Studies on Inclusive Education, 2005.

[17] L.U. deBettencourt, "Understanding the differences between idea and section 504. Teaching Exceptional Children, vol. 34, no. 3, pp. 16-23, Feb. 2002.

[18] S. Neena, and S. Bansal, "Study of awareness of learning disabilities among elementary school teachers," pp. 8, 2014. 